\title{
Globalization, National Identity and Foreign Policy: Understanding 'Global Korea'
}

\author{
JOJIN V. JOHN
}

\begin{abstract}
One of the striking themes in contemporary South Korean foreign policy is a strong emphasis on achieving seonjinguk (advanced nation) status in international affairs, as articulated in the slogan 'Global Korea'. Engaging with the discourse of globalization, the concept of seonjinguk has provided Korea with an interpretive framework for discussions of its national identity and global position. The historical experience of Korea as a hujinguk (backward country) underlies the emphasis accorded to the goal of becoming seonjinguk. The article argues that the discursive practice of Global Korea was not merely a point of departure in Korean foreign policy but was also the key site of Korean national identity construction. Through an exploration of the historical context and diplomatic practice of constructing Global Korea, it illustrates the continuity and authority of the discourse of seonjinguk in interpreting and constructing Korean national identity.
\end{abstract}

Keywords: South Korean foreign policy, Global Korea, Korean national identity, Globalization-Segyehwa, Seonjinguk discourse

\section{Introduction $^{1}$}

In the run-up to assuming the G20 presidency in December 2009, South Korea's (hereafter: Korea) former president, Lee Myung-bak, announced that 'Korea will come into global focus as a host of the G20 summit and by taking on that responsibility, will become a genuinely advanced nation'. ${ }^{2}$ Furthermore, Korean media viewed the selection of Seoul as the venue for the 2010 G20 Summit, for the first time outside the G8 and as the first Asian country to host the event, as the international community's recognition of Korea as an advanced nation. ${ }^{3}$ The hosting of the G20 Summit was celebrated in the mood of a national festival. It was widely viewed as a great boost to national pride and an instant enhancement of Korea's international image. The Seoul G20 Summit was the first major international diplomatic event hosted by Korea. Following the summit, 
Seoul hosted the fourth High-Level Forum on Aid Effectiveness in 2011 and the second Global Nuclear Security Summit in 2012, marking Korea's arrival as an influential actor in international affairs.

Hosting high profile international diplomatic events was among a range of new foreign policy initiatives undertaken under the slogan Global Korea by the Lee Myung-bak administration after assuming office in 2008. The primary objective of the Global Korea vision is to achieve advanced nation status in international affairs. On unveiling the new administration's foreign policy, foreign minister Yu Myunghwan stated: 'we will focus on nurturing Korea into a truly advanced and globally prestigious country, the vision embraced by the new government, taking us closer to fully realising the goal of building a truly Global Korea' (MOFAT 2008:5). Under the Global Korea banner, Seoul initiated an array of diplomatic practices of a scale and scope unprecedented in Korean history.

The interpretative scope of Global Korea rhetoric reached beyond diplomacy and into almost all areas of Korean public policy under the Lee administration. However, its articulation in foreign policy was particularly strong and it has received significant attention from the academic community. The bulk of literature on the subject focused on mapping the transformation of Korea's foreign policy and describing various diplomatic initiatives under the Lee administration (Han 2008; Ikenberry and Mo 2013; Olbrich and Shim 2012; ${ }^{4}$ Snyder 2012). According to these studies, Global Korea is a manifestation of the Lee administration's determination to translate Korea's economic clout into political influence in a rapidly changing world. In a critical analysis, Watson (2011) views Global Korea as the product of an elitist and state-led reappraisal of Korea's national interests and national security in relation to globalization. Kalinowski and Cho (2012) contend that leadership and opportunity-seeking behaviour articulated in the Global Korea is merely an adaptation of the mercantilist developmental state under the conditions of globalization, as a means to securing the foundations for sustained economic growth.

However, the existing debates on Global Korea do not attempt to position the strategy in a historical context. For example, one key dimension of Global Korea foreign policy was its projection of Korea as a 'middle power'5 (see John 2014; Lee 2012; Saxer 2013; Shin 2015). The Lee government was the first to adopt the middle power rhetoric officially into Korean foreign policy, and Global Korea was the platform to launch Korea's middle power diplomacy. However, the scholarship on 
the subject failed to recognize the analytical distinction between middle power identity and advanced nation status, nor the linkage between the two in the Global Korea context.

This article is an attempt to provide an alternative reading of Global Korea foreign policy and how the vision came into being, from the vantage point of national identity at the interface of globalization and foreign policy. In doing so, the notion of advanced nation articulated in the Global Korea foreign policy discourse is problematized. The theme of achieving advanced nation status is not new in Korean foreign policy discourse, but rather illuminates the continuing influence of globalization discourse on Korean foreign policy since the early 1990s. Diplomatic globalization as a means to achieving advanced nation status was first articulated under the slogan segyehwa (globalization) ${ }^{6}$ in the mid 1990s by President Kim Young-sam, and it continued to quietly inform foreign policy discourse during the progressive governments of the 2000s, only to vigorously resurface under the conservative administration of Lee Myung-bak.

This article aims to show that the discourse of Global Korea was not merely a point of departure in Korean diplomatic practice but was also the key site of Korean national identity construction, as manifest in the discourse of achieving seonjinguk (advanced nation) status through development. ${ }^{7}$ However, in the context of globalization, the scope of the discourse of seonjinguk has been expanded on the pretext of meeting a 'global-standard' in every aspect of Korean public life. In particular, it was applied to Korean foreign policy, which was often viewed as 'catching up' with the diplomatic practices of certain Western countries.

The article is organized in five thematic sections. The introduction is followed by a discussion of Korean national identity dynamics under the influence of globalization. The third section discusses the influence of seonjinguk discourse in the framing of Korean foreign policy, under different regimes, thus tracking the evolution of Global Korea. The fourth section focuses on Global Korea as a diplomatic practice, its interpretation and connection with seonjinguk. The concluding section discusses key aspects of Global Korea diplomatic practices.

\section{Globalization and Korean National Identity}

Globalization has been avidly discussed in the post-Cold War period. The excitement of engaging with globalization was such that the Korean government under President Kim Young-sam adopted its Korean 
translation, segyehwa, as official policy and pursued it vigorously. Globalization was viewed as the most expedient way for Korea to become a world-class, advanced nation. According to Samuel Kim 'no country in the post-Cold War world cast its lots with globalization as decisively or as publicly as Korea' (2000a: 2). However, the relationship between globalization and national identity is complex and multifaceted, as both concepts are theoretically contested. The existing literature mostly links national identity with ethnicity (Kim 2000a, Shin 2003). These studies observed that Korea simultaneously exhibits both strong nationalist and globalizing tendencies, but they fall short of providing a convincing explanation for the coexistence of globalism and nationalism. This has been called the Korean paradox, on the premise that one position is antithetical to the other. This article does not seek to address this 'paradox' but instead, by historicizing Global Korea, aims to shed some light on the context and conditions that enabled Korea to exhibit strong nationalist and globalist tendencies simultaneously.

Drawing on post-structural theories of identity, the article assumes that national identities are specific forms of discursive social identities, produced, reproduced, transformed and destructed by means of language and other semiotic systems (De Cellia et al. 1999: 153). It also assumes that there is no single national identity in an essentializing sense, but rather different identities are discursively constructed according to the context, depending on the social field, situational setting of the discursive act, and the topic being discussed. Thus, national identities are to be understood as dynamic, fragile, vulnerable and often incoherent against the conventional understanding of national identity as consistent, stable and immutable (Ibid.: 154). The discursive features of national identity not only allow for the possibility of the existence of different identities at different points in history, but also enable coexisting identities at any given point of history.

Developmentalism is another theoretical framework that has been influential in discussions of national identity and the worldviews of many countries in the post-WW2 period (see Escobar 1995; Nederveen 2009). The present study focuses on the discourse of developmentalism in Korea, towards understanding national identity dynamics in the context of globalization. An aspect of the Eurocentric world order, developmentalism was present in Korea through the discourse of seonjinguk and became the most influential discursive framework for the interpretation of Korean national identity in the world during the second half of the twentieth century. ${ }^{8}$ Kim (2011a) observes that the discourse 
of seonjinguk is a historically constructed knowledge system based on the conceptual relationship between seonjinguk and hujinguk, which more or less reflects the classificatory distinction between 'developed' and 'underdeveloped' in the Eurocentric developmental model. In the hierarchical distinction between seonjinguk and hujinguk, the former takes the latter as its alienated other, and has provided a justification for Korea's effort to 'catch up' with seonjinguk (Kim 2012: 83).

The evolution of the discourse of seonjinguk in Korea can be traced to the founding of the developmental regime in the 1960s (Kim 2011a). The developmental agenda and national vision of Park Chung-hee, who seized power through a military coup in 1961, was the point of departure for Korea's developmental trajectory and national identity.

In the discourse of developmentalism, seonjinguk has become an ideal image for the transformation of Korean society, an urgent national goal and a central reference point. Eurocentrism runs through the discourse of seonjinguk, and shapes the normative model of an advanced, normal and a mature being (Kim 2012: 119). Kim categorized the representation of seonjinguk in two types: concrete and abstract (2011a: 102). The concrete type referred to particular countries, international institutions and international status groups. High income Western countries and Japan were typically represented as seonjinguk. The Organisation for Economic Co-operation and Development (OECD), OECD - Development Assistance Committee (DAC), and Annexe 1 of the Kyoto Protocol etc. were often represented as the club of seonjinguk. As an abstract entity, seonjinguk was represented as a national goal, national status, and as the most desirable level or type of attainment. Like any other discourse, the discourse of seonjinguk is dynamic and its assumptions and representations of Korea's historical transformation have been affected by various factors at the national and global level. This fluidity is also manifest in the different governmental slogans adopted by successive Korean governments in their efforts to utilize the authority of the seonjinguk ideal. Three key slogans can be identified: (1) guendaewa (modernization), during authoritarian regimes from the early 1960s till the mid-1980s; (2) segyehwa during the 1990s; and (3) seonjinwa (achieving advancement) since the late 2000s (Kim 2014).

The Park regime was both anti-communist and pressing for economic development. It produced a new, synthetic discourse of authority by combining the ethos of development and anti-communism with nationalism under the slogan joguk geundaehwa (modernization of the motherland). When the regime assumed authority in the 1960s, it defined 
Korea's status as hujinguk in the international community, problematizing Korea's poverty, its backward economy and traditional ways of life. Informed by the discourse of seonjinguk, the most urgent national goal for the Park regime was to escape from the status of hujinguk (Kim 2011a).

The authoritarian regime of Chun Du-hwan in the 1980s inherited much of the Park administration's legacy and continued the pursuit of national economic development. During this period, the discursive field of the seonjinguk discourse was limited to the fields of economy, industry and technology. The discursive power of seonjinguk was instrumental in the ideological foundations of Korea's 'catch-up' economic model.

The discourse of seonjinguk has undergone a significant transformation under the influence of globalization since the late 1980s. Having achieved industrialization and democratization, Korea was in need of a different development model: the aim was to 'upgrade Korea' to effectively meet the global challenge (Park 2006). The Kim Young-sam administration (1992-97) launched segyehwa as the official globalization policy. In his New Year's address in 1995, President Kim promulgated the need for segyehwa as a way for Korea to face international competition, which was viewed as both a crisis and an opportunity (Kim 1997). ${ }^{9}$ Korean elites considered globalization as a universal trend and thus enthusiastically advocated globalization as the route to global competitiveness and advancement (Kim 2012: 80). The segyehwa policy was unique as it set out to globalize the country through a state-enhancing, top-down strategic plan with the purpose of meeting the challenge of globalization as defined by the government (KOIS 1995). The Globalization Committee argued that:

The 'segyehwa' policy purports to adapt actively ourselves to the changes taking place and to promote development, thus not to repeat the failures of the past. In other words, this is a strategy to reform our consciousness and the institutions [...] ultimately to become an central country of the world in the future. (PSPC: 22-23, author's translation)

The Kim Young-sam government approached Korea's national identity as almost 'seonjinguk' in its domestic and foreign affairs, but the desire to achieve the status was stronger than ever before. Following Korea's entry into OECD in 1996, the building of full-fledged seonjinguk was accepted as a tangible national vision that was imminently achievable (Kim 2011b: 335).

During this period, the discourse of seonjinguk underwent critical transformations. Three changes were very significant. First, the concept of seonjinguk became far more popularized and naturalized in its use 
in public; its connotations also became more generalized and idealized (Kim 2011b: 333). The second change was the expansion of the discursive field of seonjinguk beyond economic matters, to permeate almost every aspect of Korean public policy, including education, diplomacy, the environment, labour, health, etc. The third change reflected the transformation and consolidation of democracy in Korea. Though not challenging the discursive structure and authority of seonjinguk discourse, an interpretative rift appeared between the conservative and progressive factions in Korean politics. Conservatives argued for a seonjinguk ideal that favoured freedom, growth and gradual reform towards capitalism. They supported a free market economy, much in line with the American version of neoliberalism. In contrast, the progressive camp embraced democratic values and the ideals of a welfare state; they identified with the Western European model that favoured equality and a fundamental reform of capitalism through government intervention (Son 2014: 5).

To meet the challenges of the Asian financial crisis, the new Kim Daejung administration embraced the content of segyehwa policy from the outset of its inauguration in 1998. President Kim utilized the discursive authority of seonjinguk discourse to overcome domestic resistance to implementing structural adjustment programmes prescribed by the IMF. The neoliberal reforms were appropriated as a necessary step towards achieving seonjinguk status (Kim 2011b: 339). However, during the Kim Dae-jung and Roh Moo-hyun regime, the discursive focus of seonjinguk was more pluralistic and populist, in keeping with their progressive politics. Under the slogan 'Universal Globalism' the ideals of seonjinguk were articulated in terms of democracy, liberty, freedom, welfare, human rights, etc.; this aligned with their agenda of intensifying democratization and building a welfare state. ${ }^{10}$

The return of conservative government under President Lee Myung-bak in the post-2008 financial crisis period witnessed the return of a strong seonjinguk discourse used to appropriate public policies and national identity. Under President Lee, the seonjinguk discourse was promulgated through the slogan of seonjinhwa and was central to the government's vision for Korean identity (Chung and Park 2010; Im 2014; Kim 2014). Park defined seonjinhwa as the development and implementation of new strategies, including (a) economy (USD 30,000 per capita income era) ${ }_{i}^{11}$ (b) politics (supporting liberal democracy instead of populism); (c) society (finding an appropriate balance between private and public interests); (d) culture (the creation of a global culture); and (e) international relations (making a global contribution). ${ }^{12}$ At its core, 
seonjinhwa rhetoric articulated the essence of a neoliberal vision of collective efforts to realize globalized and post-modern goals for progress through innovation (Son 2014: 5). In President Lee's vision, seonjinhwa represented the later stage of development, a necessary foundation upon which Korea would become an advanced nation. ${ }^{13}$

\section{Globalization and Korean Foreign Policy}

During the Cold War period, the influence of the discourse of seonjinguk was limited to the field of economy and had no real impact on foreign policy. Korean foreign policy during the Cold War period focused primarily on national survival in the event of a North Korean military invasion, and on maintaining the legitimacy of the Korean regime in the international community. Korean foreign policy was guided by the slogan bukuk gangbyong (rich state, strong army) and promoted a strong anti-communist national identity (Moon and Kim 2004: 252). Segyehwa policy, however, was not just about making the necessary domestic changes to make Korean economy competitive, it was also a call for the fundamental transformation of every aspect of Korean public policy including international affairs - in order to achieve seonjinguk status. This ambition built on the legacies of rapid economic development and the confidence gained on hosting the hugely successful Olympics Games in 1988 (Lee 2000). ${ }^{14}$ The Korean government wanted to show the world that Korea was no longer a poverty-stricken Asian war victim but a strong, modern and increasingly prosperous country with a vibrant society. The success of the Seoul Olympics inculcated the populace with a sense of national pride and a heightened awareness of internationalism (Lee 2000: 177).

Han Sung-joo, the foreign minister of Kim Young-sam administration, articulated segyehwa as a key component of Korea's 'New Diplomacy' (Sin Oegyo). It was framed as the first of five basic themes relevant for Korea's foreign policy outlook: globalism, diversification, multi-dimensionality, regional cooperation and future orientation (Gills and Gills 2000: 95). Advocating a new foreign policy vision to meet the global diplomatic standard of advanced nations, Han argued:

[W]ith the advent of the era of globalism, Korea's diplomacy needs to pay more attention to such universal values as freedom, justice, peace and welfare... We will take an active part in international efforts to tackle global issues such as international peace and security, disarmament and arms control, eradication of poverty, protection of environment, and efficient 
utilisation of natural resources. Through such agreements, we will play our due part in making a more just, safe and prosperous world. (quoted in Koh 2000: 198)

Under segyehwa, achieving advanced national status in international affairs was interpreted as expanding Seoul's diplomatic reach across the globe and participating in major international organisations, such as the UN and OECD. Since the late 1980s, Seoul has made efforts to expand and diversify its diplomatic engagements. The number of countries with whom Korea has formal diplomatic relations has steadily increased from 126 in 1985, to 146 in 1990, to 186 by the end of 1998. As of November 2015, Korea has diplomatic relations with 190 countries. ${ }^{15}$ Korea's membership of intergovernmental organizations (IGO) likewise increased from 36 in 1985 to 52 in 1998; and its membership of international intergovernmental organisations (INGOs) increased from 686 to 1250 in the same period (Lee 2000). According to Samuel Kim (2000b: 265), the global reach of Korean foreign policy began to flourish in the 1990s: through Korea-Russia normalisation (1990), Korea's UN membership (1991), Korea-China normalisation (1992), Organisation for Economic Cooperation and development (OECD) membership (1996) and UN Security Council membership (1996-97). In 1997, the Korean Foreign Ministry renewed its pledge to work towards 'globalization diplomacy' so that the government could respond more effectively to fluctuating international situations and make Korea a 'first-rate advanced nation' (MOFAT 1997: 108). The Korean Foreign Ministry emphasized the growing importance and influence of the UN, stating:

[A]s the UN expected to play a greater role in dealing with such global issues as disarmament, environment, human rights and narcotics in the post-cold war period, our nation should pursue an active UN diplomacy to secure the maximum level of our national interests and to assume a role commensurate with our position in the international community (ibid.).

Lee observed that UN-oriented global diplomacy enjoyed broad popular support in Korea and also promoted membership in prestigious international organisations including the OECD and the World Trade Organisation (WTO) (2000: 117). Samuel Kim noted that segyehwa was viewed by many Koreans as a passport into the OECD and the UN Security Council; it was how Korea would become 'a central player on the world stage' (Kim 2000b: 244).

In 1991 the Korea International Cooperation Agency (KOICA) was established to expand Korea's grant aid programmes for developing countries. This was a way to show the world Korea's successful trans- 
formation from a recipient of aid to a donor, the first country to do so. Lee noted that official development assistance (ODA) discourses in the 1990s centred on two themes: to make Korea an advanced country and to globalise the national experiences of Korean economic development (2003). Lee also observed that Korean ODA policy under segyehwa policy increasingly attracted civil society partnerships, reflecting the popular support for and national pride in Korea's change of status from recipient to donor.

Korean foreign policy under Kim Dae-jung continued to use the discursive authority of seonjinguk to influence the economic domain and was instrumental in deepening neoliberal reform in the post-financial crisis context. But it was more regionally oriented and there was less rhetoric about achieving seonjinguk status in international affairs. President Kim argued for 'a new language of nationalism calling for national unity to survive and gain leadership in the international community' (Park 1996). ${ }^{16}$ Under the new nationalist discourse, President Kim initiated the Sunshine Policy, the engagement and reconciliation approach to inter-Korean relations.

Roh Moo-hyun (2002-2007) picked up where his predecessor left off by championing inter-Korean engagement and reconciliation. Like President Kim Dae-jung, President Roh framed his foreign policies in peninsular and regional terms (Levin and Han 2002). However, the rhetoric of achieving advanced nation status in the official foreign policy discourse under President Roh shifted from participatory governance towards a neoliberal free-trade agenda, in order to make Korea an 'advanced trading nation'. ${ }^{17}$

2008 saw the end of a decade of progressive rule with the return of conservative government under President Lee Myung-bak. Achieving advanced nation status for Korea in international affairs by building Global Korea was the stated objective of the Lee administration's foreign policy (Cheong Wa Dae 2009). Global Korea was officially defined as:

[A] Republic of Korea that not only cooperates actively, but also offers solutions for dealing with common issues facing the world community. [....] Korea that leaves behind a habit of diplomacy narrowly geared to the Korean Peninsula, and adopts a more open and enterprising posture that sees the world stage as the appropriate platform for its foreign policy and national interest... the time is now ripe for Korea to strive to become a more dignified country and to find its place among the ranks of advanced nations. This is what the Lee Myung-bak Administration's vision for a Global Korea aspires to achieve. (Cheong Wa Dae 2009: 12) 
Korean foreign policy under Global Korea was a major departure from the previous administration's foreign policy outlook. ${ }^{18}$ It is important to recognize that Global Korea was not merely a strategy but also a hugely popular aspirational identity for Korea in the international community (Lee 2011).

Advanced nation status was not the only identity articulated in the Global Korea foreign policy; it also emphasized middle power identity (junggyun guk) (John 2014; Lee 2012; Saxer 2013; Shin 2015). Global Korea's advanced nation status and middle power identity are quite inseparable. Nonetheless, although they may appear to be performing similar foreign policy functions in the context of Global Korea, they are two different identities presenting different conceptions of national identity. As noted, seonjinguk status is associated with general ideals of development or progress, mostly interpreted in material terms. In contrast, middle power identity is associated with the status and foreign policy behaviour of a country that has positioned itself in between great powers and small powers, in terms of the hierarchical ranking of countries defined according to power capabilities.

In terms of its power attributes, Korea was clearly a middle power. However, it was only during the Lee government that Korea's middle power identity was officially acknowledged and used to define Korea's international role. I argue that Global Korea is the discursive policy space where the seonjinguk and middle power identity projects met. Though the discursive authority of seonjinguk was the force underpinning the 'catch up' motivation to build Global Korea, the appropriate template for the Global Korea foreign policy was directed by Korea's middle power identity. Thus, the diplomatic practice of Global Korea can be regarded as a manifestation of Korea's efforts to catch up with the diplomatic norms and practices of advanced Western middle power countries, especially Australia and Canada. ${ }^{19}$

\section{'Global Korea' Diplomatic Practice}

The Lee administration's Global Korea foreign policy was a clear departure in terms of the reach and scale of diplomatic activism in comparison with previous administrations. Through Global Korea foreign policy, Korea sought to influence and shape sustainable political, legal, socio-economic, security and ideational structures at the international level. It emphasized selected international issues, like international development, peace-keeping and environment, and it initiated a range 
of new diplomatic practices like hosting international meetings, nation branding, public and cultural diplomacy, etc.

At the outset, Global Korea strategy had a strong emphasis on national image and international reputation. President Lee initiated a widely publicized nation branding campaign and created the Presidential Council on Nation Branding (PCNB) in 2009. The PCNB was born out of the government's concern over the gap between Korea's successful economic development and its image and reputation in the eyes of foreigners. In response to the relatively low performance of Korea in the Anholt-GfK Roper Nation Brand index, President Lee announced his intention to raise Korea's rank from 33rd in 2008 to 15th in 2013. ${ }^{20}$ In his address to the nation, President Lee said:

[It is] extremely important for Korean people to earn the respect of the international community. [...] Korea is one of the most advanced nations technologically. Still, the first images that come to mind to foreigners are those of strikes and street demonstrations. If our nation wants to be 'labelled' as a developed country, it needs [...] to improve its nation brand and its reputation significantly. Korea's national brand value is only 30 per cent of our economic power... I will upgrade our national brand value to that of an advanced nation during my term of office. ${ }^{21}$

The PCNB has undertaken a ten-point action plan. ${ }^{22}$ These plans include the global promotion of Taekwondo (Korean martial art); creation of a service of international volunteers (World Friends Korea); ${ }^{23}$ to adopt a 'Korean Wave' programme; ${ }^{24}$ to introduce a Global Korea Scholarship; to adopt a campus Asia programme; to increase external aid; to develop state of art technologies; to nurture the culture and tourism industries; to treat foreigners and multicultural families better; and to help Koreans become 'global citizens'. ${ }^{25}$ The Korean government also employs cultural diplomacy to enhance Korea's image: there are initiatives to subsidize the production of dramas, movies and documentaries targeting overseas screenings, in order to sustain the Korean Wave. The Korean language is also being promoted overseas through the establishment of $500 \mathrm{King}$ Sejong Institutes by $2015 .{ }^{26}$

As previously noted, the hosting of high-profile international meetings was another diplomatic practice initiated under Global Korea. Hosting and chairing the 2010 G20 set a solid foundation for Seoul's leadership role. In late 2011, Korea hosted the 4th High-Level Forum on Aid Effectiveness at Busan and helped to bridge Western donors and developing countries by bringing the development agenda into the conventional aid effectiveness agenda. Korea hosted the 2nd Nuclear 
Security Summit in March 2012, the largest summit in the security field, involving more than 53 heads of state and international organizations (Lee 2012). From Seoul's perspective, organizing the event was not only an opportunity to influence the agenda but also, more importantly, to get Korea into the limelight.

Increasing Korea's contribution to the global public good, like international security and peacekeeping, was interpreted as another step towards building Global Korea. The Lee administration emphasized Korea's transformation from a consumer to a producer of international security, in keeping with Western foreign policy rhetoric (Snyder 2012). The peacekeeping initiative included: the establishment of a 3000-strong standing unit dedicated to overseas deployments; legislation to authorize the deployment up to 1000 Korean personnel for UN peacekeeping operations (PKO) without prior approval from the Korean National Assembly; and the establishment of a PKO centre dedicated to the training of military personnel to be dispatched for overseas assignments (Chung 2010: 98). Post-conflict resolution is another area to which Korea contributed through the establishment of a Provincial Reconstruction Team (PRT) of 336 personnel in Afghanistan. ${ }^{27}$

Under the Global Korea strategy, Korea's role in international development strengthened. Korea's developmental activism is largely built on the experience of having been a former aid recipient that became a donor. Just a few months after assuming office, the Lee administration sought membership of OECD-DAC. Responding to Korea's OECD-DAC entry in 2010, the Korean Foreign Ministry observed that 'by joining the DAC, Korea has been officially recognized as a country that has transformed itself from an emerging donor to an advanced donor. It will help enhance Korea's status by reaffirming its determination to make contributions to the international community'. ${ }^{28}$ Under the Global Korea vision, Korea has substantially expanded its development assistance, increasing its ODA by 65 per cent, from approximately USD 700 million in 2008 to USD 1.2 billion in 2011. Korea's ODA of approximately USD 1.2 billion is 0.12 per cent of the country's gross national income, less than the DAC average of 0.32 per cent. Seoul has pledged to increase this figure to 0.25 per cent by 2015 (John 2014).

Another Global Korea agenda was to promote the model of 'Green Growth', and to thus play a larger role on the issue of global warming and climate change. The concept received global attention when Korea adopted 'low carbon green growth' as its new development vision, which was swiftly followed by the release in 2009 of its National Strategy for 
Green Growth and the Five-Year Plan for Green Growth. This vision was reflected in several international initiatives designed to reframe the status of Korea's environmental policy, presenting the Green Growth model as an innovative and uniquely Korean answer to sustainable development (Ikenberry and Mo 2013; Shim 2010). The Global Green Growth Institute (GGI) was established in Seoul in 2010, and was later elevated to international organization status at the Rio+20 Conference in 2012; it was the first Korean-led international organization. Through the institutionalization of the Green Growth agenda at global level, Korea sought to enhance its visibility and leadership capacity (O'Donnell 2012). ${ }^{29}$ The Lee administration also sought to establish its visibility and moral authority by announcing an ambitious target for the reduction of carbon emissions to the standard levels of the annexe 1 countries of the Kyoto Protocol, even though Korea was classified as 'developing' in climate terms. Announcing this action, President Lee said 'South Korea can boost its national status and pride by voluntarily announcing an emissions target'..$^{30}$

\section{Conclusion}

This article set out to historicize the evolution of Global Korea, to provide an alternative reading of contemporary Korean foreign policy from the vantage point of national identity politics in the context of globalization. It focused on the continuity and authority of seonjinguk discourse and its influence on Korean foreign policy. The article demonstrated that in order to be perceived as an 'advanced nation', Korea aimed to achieve seonjinguk status not only in the economic field but in all domains of Korean life, including diplomatic practices. Thus, the globalization of Korean foreign policy means meeting the demand to 'catch up' with the diplomatic standards of seonjinguk.

However, Korea's international role was vaguely defined, reflecting abstract and ambiguous representations of seonjinguk diplomatic standards in Korean foreign policy discourse, interpreted as expanding Seoul's diplomatic reach across the globe and participating in international organizations. OECD membership in 1996 was regarded as a significant event in the transformation of Korea's status in international affairs, as a nation at the threshold of achieving advanced nation status. Although the progressive governments under Kim Dae-jung and Roh Moo-hyun used the discursive authority of seonjinguk in pushing forward appropriate economic and political reforms, it was utilized less in their foreign policy. 
The return of a conservative regime in 2008 under President Lee Myung-bak marked the reassertion of the discourse of seonjinguk in Korean identity and nation branding, particularly in international affairs. Global Korea was the discursive site where the assertion of middle power identity and the project of achieving seonjinguk status converged. Middle power identity provided a clear template for the shaping of Korea's diplomatic practice and international role, under the unifying slogan of Global Korea.

Jojin V. John is a Post-Doctoral Fellow at the Centre for East Asian Studies, Jawaharlal Nehru University, New Delhi. Email: johnjojin@gmail.com

\section{NOTES}

1 I would like to thank the organizers and participants of the international workshop 'Beyond Borders: Connectivity and Identities of Change in East Asia' which took place at Universiti Sains Malaysia, Penang on 13-14 December 2012. I also thank Dr Jitendra Uttam and the anonymous reviewers of CJAS for their valuable support and comments.

2 Quoted in Oliver, Christian 2009. 'S Korea to come of age with G20 leadership.' The Financial Times. 31 December 2009. http:/ / on.ft.com/1OB7VOZ. Accessed 31 January 2013.

3 Lee, Chi-dong 2010. 'Successful hosting of G-20 summit boosts Korea's global leadership'. Yonhap News, 12 November. http:// bit.ly/1MysVTj. Accessed 31 January 2013.

4 Olbrich, Philipp and David Shim 2012. 'South Korea as a Global Actor: International Contributions to Development and Security'. Giga Focus No. 2. http://bit. ly/1RaD2zm. Accessed 3 June 2014.

5 In international relations the concept 'middle power' is used refer to and distinguish between the status of certain countries that are neither great nor small powers, but which have substantial influence and international recognition. Middle power status is usually identified in one of two ways. The traditional and most common way is to aggregate critical physical and material criteria to rank states according to their relative capabilities. Countries that fall in the middle range of the spectrum are identified as middle powers. Aggregate national capability of a country is calculated combining economic, demographic, physical, military and defence capabilities. The other way to distinguish a middle power from great powers and smaller powers is their foreign policy behaviour - middle powers carve out a niche for themselves by pursuing a narrow range and particular types of foreign policy interest. In this way middle powers are countries that use their relative diplomatic skills in the service of international peace and stability. The political meaning and images of 'middle power' concept is mostly based on Canadian and Australian foreign policy activities in the post-WW2 period. (See Jordaan 2003; Stairs1998).

6 Segyehwa is the Korean word for globalization, used by the Kim Youn-sam administration for its globalization policy. Korean academics, media practitioners, activists, politicians, policymakers, business entrepreneurs and journalists constructed multiple interpretations of segyehwa: 'it was a strategic principle, a mobilizing slogan, 
a hegemonic ideology, and a new national identity badge for a state aspiring to advanced world-class status'. (Kim 2000b: 244).

7 The literal translation of seonjinguk is 'forward-going country', or advanced country, and hujinguk is 'backwards-going country' or under-developed country. In the official translation it is often translated as advanced nation, hence this article uses 'advanced nation'. In the text advanced nation and seonjinguk are used interchangeably as synonyms. The approach of the article draws inspiration from the post-structural theory of foreign policy, beginning with an assumption that foreign policy, the most authentic and authoritative narrative of the nation-state, is a key site of national identity construction. The post-structuralist holds the view that state and other political actors strive to uphold a particular vision of themselves and that they do so through policy discourses. Foreign policy discourses play a crucial role in the construction of these visions as they draw a line between the state and what makes up national identity on the one hand and that which is different and outside the scope of the state on the other (See Hansen 2012; 2006). The 'self' and 'other' relation inherent in the discourse of seonjinguk is constructed around the hierarchical concepts of seonjinguk and hujinguk. The most significant feature of the discourse of seonjinguk is the hierarchical distinction between seonjinguk and hujinguk, in which the latter is the former's alienated other, providing a historical justification for Korea's effort to 'catch up' with seonjinguk. The self-other relations between seonjinguk and hujinguk presented in this article are more temporal in nature and internal in character. Thus, 'hujinguk' was the alienated other of the desired 'seonjinguk' identity of Korea in the initial stage of modernization in the early 1960s.

8 The formation and transformation of the discourse of seonjinguk should be understood in the context of the global discursive transition that accompanies changes in power relations. At the global level, the post-war period can be characterized by a discursive transition from the discourse of civilisation to that of development, which accompanied the power change from the hegemony of Europe to that of the U.S. Reflecting this, the formation of the discourse of seonjinguk in the 1960s was conditioned by the decline of the munmyorng (civilization) discourse and the rise of the South Korean developmental regime (Kim 2011: 181).

9 Kim, Young-sam 1997. Korea's Quest for Reform and Globalization: Selected Speeches of President Kim Young-sam, Volume II. Seoul: Office of the President. The Republic of Korea.

10 President Kim Dae-Jung's inaugural address, 26 February 1998, http:/ / shlel.tripod. com/krinaug.htm. Accessed 12 December 2014.

11 Achieving per capita income of USD30,000 is viewed as a basic criterion for Korea to be designated as seonjinguk. President Lee also held this idea of seonjiguk. For instance on addressing the nation President Lee said, "If Korea can get past the critical point of US $\$ 30,000$ in per capita income, it should be able to open an era of USD40,000 and USD50,000 without too much difficulty. Now is a crucial time for Korea to soar into an advanced country. We cannot afford to miss this opportunity". See 'Address by President Lee Myung-bak on the 63rd Anniversary of National Liberation and the 60th Anniversary of the Founding of the Republic of Korea', 15 August 2008. http://www.korea.net/Government/Briefing-Room/PresidentialSpeeches/view?articleId=91000. Accessed 6 November 2015.

12 Park, S. National goals for the completion of liberal democracy, trust society, the creation of a global culture, and world contributing nation [Jayuminjuju-ui wanseong, sinroesahoe, muhwabalsinguk, segye gongheonguk-i mokpyo], Monthly Chosun, January 2009. http:// monthly.chosun.com/client/news/viw.asp?ctcd=\&nNewsNumb=2009011 00092. Accessed 7 November 2015. 
Jojin V. John

13 Address to the nation by President Lee Myung-bak before leaving on a trip to the United States and Japan, 13 April 2008. http:/ / bit.ly/1FCiqyK. Accessed 2 December 2014.

14 Lee, Sang-hyun 2012. The Nuclear Security Summit and South Korea's Growing International Role. Zurich: The International Relations and Security Network (ISN). http:/ / bit.ly/1KDJXPr. Accessed 21 January 2014.

15 Ministry of Foreign Affairs, Republic of Korea. http://www.mofa.go.kr/ENG/ ministry/relations/index.jsp?menu=m_50_120. Accessed 8 November 2015.

16 Park, Hyun Ok 1996. 'Segyehwa: Globalization and Nationalism in Korea'. Journal of the International Institute 4(1). http:/ / bit.ly/1KEzFhO. Accessed 2 December 2014.

17 Hankyoreh 2005. 'Go Slow With 'Advanced Trading Nation' Plans'. http://bit. ly/1iD8Px8. Accessed 21 December 2014.

18 Besides globally oriented diplomatic activism, other key features of Korean foreign policy under the Global Korea banner are as follows. First, Lee adopted a hard-line approach to North Korea, a complete turnaround from the engagement policy of his predecessors, Kim Dae-jung (1998-2003) and Roh Moo-hyun (2003-2008). Second, he promoted a strong US-Korean strategic alliance, which was at its lowest point during the previous administration. Third, the 'New Asia Initiative' promoted greater engagement with Asian countries. See Sohn and Kang 2013.

19 Since the initiation of Global Korea foreign policy, Seoul has evolved to become the hub for academic and policy debates on middle powers. In shaping Korea's middle power diplomacy many efforts have been made to learn from the experience of traditional middle power countries like Australia and Canada through initiatives like academic and policy conferences, speaker series featuring former ambassadors from Canada and Australia, academic publications, think-tank interactions, etc. See Middle Power Diplomacy of Canada and Its Implications for South Korea's Foreign Policy, Seoul: EAI.http://www.eai.or.kr/type/panelView.asp?bytag=p\&code=eng_ report\&idx=12129\&page=1; Middle Power Diplomatic Strategy of Australia and Policy Recommendations for South Korea's Middle Power, Seoul: EAIhttp://www.eai.or.kr/ type/panelView.asp?bytag=p\&code=eng_report\&idx=12525\&page=1. Accessed 3 December 2014.

20 This is an index based on the concept of measuring the global perception of a country in several spheres. It was developed by Simon Anholt and is now called 'The AnholtGfK Roper Nation Brands Index'. Despite much effort South Korea was ranked 27th in the 2014 Anholt-GfK Roper Nation Brands Index (NBI) overall brand ranking. http:/ / eng.ajunews.com/view/20141114091441183. Accessed 3 December 2014.

21 Lee Myung-bak, Presidential speech during South Korea's Independence Day,15 August 2008. http:/ / bit.ly/1P0FrxD. Accessed 3 December 2014.

22 Brand Korea's 10-point action plan unveiled; Nation Branding, 25 March 2009. http:/ / bit.ly/1R9JmHy. Accessed 3 December 2014.

23 In 2009 the Korean government initiated World Friends Korea, a program that will send over 3,000 volunteers to developing countries every year. See http://www. worldfriendskorea.or.kr.

24 Named after the Korean culture boom that has swept across Asia, this programme aims to help developing countries achieve rapid economic development like South Korea did by providing them with technological support.

25 This is an initiative to foster a greater sense of multiculturalism and open-mindedness in Korean society by promoting exchange programmes, sending volunteers abroad, and establishing cultural centres to educate domestic Koreans about other cultures.

26 In promoting Korean image internationally through the promotion of Korean lan- 
guage, in 2010 the government unified all the Korean language institutes around the world under one title, the King Sejong Institute (named after the famous king who invented hangeul, the Korean alphabet). This is akin to France's Alliance Française or Germany's Goethe-Institute.

27 John Hemmings, The ROK Provincial Reconstruction Team in Afghanistan, Washington: Council for Foreign Relations. http:/ /i.cfr.org/content/publications/attachments/ GlobalKorea_report_Hemmings.pdf. Accessed 9 November 2015.

28 Ministry of Foreign Affairs, Republic of Korea http://bit.ly/1JwX298. Accessed 3 December 2014.

29 O'Donnell, J 2012. The Global Green Growth Institute: On a Mission to Prove Green Growth. Council on Foreign Relations. http:/ / on.cfr.org/1PIoF4n. Accessed 23 April 2014.

30 South Korea pledges emissions cut, Financial Times, 17 November 2009 http:/ / on.ft. com/1KNkBfT. Accessed 10 March 2014.

\section{REFERENCES}

Cheong Wa Dae 2009. Global Korea: The National Security Strategy of the Republic of Korea. Seoul: Cheong Wa Dae.

Chung, Chung-joo and Han Woo Park 2010. 'Textual Analysis of a Political Message: the Inaugural Addresses of Two Korean Presidents'. Theory and Methods 49 (2): 215-239.

Chung, Eun-sook 2010. 'Korea's Law on UNPKO and Participation in International Peacekeeping Missions'. Korea Focus 18 (2): 98-102.

De Cellia, Rudolf et al 1999. 'The Discursive Construction of National Identities'. Discourse \& Society 10 (2): 149-173.

Escobar, Arturo 1995. Encountering Development: The Making and Unmaking of the Third World. Princeton, NJ: Princeton University Press.

Gill, Barry and Dong-sook Gill 2000. 'South Korea and Globalisation: The Rise of Globalism". In Samuel Kim (ed.) East Asia and Globalisation. Oxford: Rowman and Littlefield Publishers: 81-102.

Han, Seung-soo 2008. 'Charting a New Frontier: 'Global Korea' in the Twenty-First Century'. The Adelphi Papers 48 (400-401): 103-110.

Hansen, Lene 2006. Security as Practice: Discourse Analysis and the Bosnian War. London: Routledge.

Hansen, Lene 2012. 'Discourse Analysis, Post-structuralism, and Foreign Policy'. In S. Smith, A. Hadfield and T. Dunne (eds.). Foreign Policy: Theories, Actors, Cases. Oxford: Oxford University Press: 94-109.

Ikenberry, G. John and Jongryn Mo 2013. The Rise of Korean Leadership: Emerging Powers and Liberal International Order. New York: Palgrave Macmillan.

Im, Eui-yong 2014. 'Critical Study on the Advancement Discourse of Lee Myung-bak Government' [Imyeongbak Jeongbuui Seonjinhwadamrone Daehan Bipanjeok Gochal]. Journal of Government Studies 20 (2): 355-396.

John, Jojin V. 2014. 'Becoming and Being a Middle Power: Exploring a New Dimension of South Korea's Foreign Policy'. China Report 50 (4): 325-341.

Jordaan, Eduard 2003. 'The Concept of a Middle Power in International Relations: Distinguishing between Emerging and Traditional Middle Powers'. Politikon: South African Journal of Political Studies 30(1): 165-181.

Kalinowski, Thomas and Hyekyung Cho 2012. 'Korea's Search for a Global Role between Hard Economic Interests and Soft Power'. European Journal of Development Research 
Jojin V. John

24 (2): 242-260.

Kang, Eliot 2000. 'Segyehwa Reform of the South Korean Developmental State'. In Korea's Globalisation. In S. Kim (ed.) Korea's Globalisation. New York: Cambridge University Press 2000: 76-101.

Kim, Eun Mee and Jae Eun Lee 2013. 'Busan and Beyond: South Korea and the Transition from Aid Effectiveness to Development Effectiveness'. Journal of International Development 25 (6): 787-801.

Kim, Eun Mee, Kim Pil Ho and Kim Jinkyung. 2013. 'From Development to Development Cooperation: Foreign Aid, Country Ownership, and the Developmental State in South Korea'. Pacific Review 26 (3): 313-336.

Kim, Jongtae 2011a. The discourse of sonjin' guk: South Korea's Eurocentric Modern Identities and Worldviews. Ph.D. Dissertation, University of Illinois at Urbana-Champaign.

Kim, Jongtae 2011b. 'South Korea's Historical Constructions of Advanced Country: The Discourse of Seonjinguk from the 1980s to the Present'. Society and Theory 18: 315-351.

Kim, Jongtae 2012. 'The West and East Asian National Identities: A Comparison of Discourses of Korean Seonjinguk, Japanese Nihonjinron, and Chinese New Nationalism'. In Jan Nederveen Pieterse and Kim Jongtae (eds.) Globalization and Development in East Asia. New York: Routledge: 80-97.

Kim, Jongtae 2014. 'The Discursive Structure of Developmentalism in Korea: A Comparison of Geundaehwa, Segyehwa, and Seonjinhwa Discourses' [hanguk baljeonjuuiui damron gujo: geundaehwa, segyehwa, seonjinhwa damronui bigyo]. Economy and Society [gyeongjewa sahoe] 103:166-195.

Kim, Samuel 2000. Korea's Globalization. New York: Cambridge University Press.

Kim, Samuel 2000a. 'Korea and Globalization: A framework for Analysis'. In Samuel Kim (ed.) Korea's Globalization. New York: Cambridge University Press: 1-28.

Kim, Samuel 2000b. 'Korea's Segyehwa Drive: Promise versus Performance'. In Samuel Kim (ed.) Korea's Globalization. New York: Cambridge University Press: 242-281.

Koh, B.C 2000. 'Segyehwa, the Republic of Korea, and the United Nations'. In Samuel Kim (ed.) Korea's Globalization. New York: Cambridge University Press:196-216.

Korean Overseas Information Service (KOIS) 1995. The Segyehwa Policy of Korea under President Kim Young-Sam. Seoul: Korean Overseas Information Service.

Lee, Chae-jin 2000. 'South Korea's Foreign Relations'. In Samuel Kim (ed.) Korea's Globalization. New York: Cambridge University Press:170-195.

Lee, Sook-jong 2011. 'Global Identity and South Korea's Diplomacy'. In Won-taek Kang and Nae-young Lee (eds.) Understanding Korean Identity: Through the Lens of Opinion Survey. Seoul: East Asia Institute.

Lee, Sook-jong 2012. 'South Korea as New Middle Power Seeking Complex Diplomacy'. EAI Asia Security Initiative, Working Paper 25. Seoul: East Asia Institute.

Lee, Tae-joo. 2003. 'An Anthropological Study of the Korean Foreign Aid Policy: Making Advanced Country and Development Discourse' [Hankuk ui Daeoe Wonjo Jeongchaeke daehan Inryuhakjeok Yeongu: 'Seonjinkuk Mandeulgi' wa Baljeon Damron]. Cross Cultural Studies [Bigyo Munhwa Yeongu] 9 (1): 139-174.

Levin, Norman D. and Yong-Sup Han 2002. Sunshine in Korea: The South Korean Debate over Policies Toward North Korea. Santa Monica, CA: RAND.

MOFAT (Ministry of Foreign Affairs and Trade) 1997. Diplomatic White Paper. Seoul: MOFAT.

MOFAT (Ministry of Foreign Affairs and Trade 2008. Diplomatic White Paper. Seoul: MOFAT.

Moon, Chung-in and Taehwan Kim 2004. 'South Korea's International Relations: Challenges of Developmental Realism?' In Samuel S. Kim (ed.) International Relations of 
Northeast Asia. Lanham, Maryland: Rowman and Littlefield Publishers: 251-280.

Nederveen Pieterse, Jan 2009. Development Theory. London: Sage.

Park, Se-il 2006. The Seonjinhwa Strategy of South Korea [Daehanminguk Seonjinhwa Jeonlyak]. Paju: 21segi Books.

PSPC (Presidential Segyehwa Promotion Committee) (Segyehwach'ujinuiwŏnhoe) 1998. The Segyehwa Whitepaper [Segyehwa Baekseo]. Seoul: PSPC.

Saxer, Carl J 2013. 'Capabilities and Aspirations: South Korea's Rise as a Middle Power'. Asia Europe Journal 11 (4): 397-413.

Shin, Gi-wook 2003. The Paradox of Korean Globalization. Stanford: Asia/Pacific Research Center, Stanford University.

Shin, Soon-ok 2015. 'South Korea's Elusive Middlepowermanship: Regional or Global Player?'. The Pacific Review. DOI: 10.1080/09512748.2015.101344. Accessed 30 August 2015.

Snyder, Scott A 2012. Global Korea South Korea's Contributions to International Security. New York: Council on Foreign Relations Press.

Sohn, Yul and Won-Taek Kang 2013. 'South Korea in 2012: An Election Year under Rebalancing Challenges'. Asian Survey. 53(1): 198-205

Son, Hyeonju 2014. 'Analysis of Reasons and Countermeasures for the Necessity of Alternative Futures Discourses in South Korea'. Futures 55:1-14.

Stairs, Denis 1998. 'Of Medium Powers and Middling Roles'. In Ken Booth (ed.) Statecraft and Security: The Cold War and Beyond. Cambridge: Cambridge University Press.

Watson, Iain 2011. 'Global Korea: Foreign Aid and National Interests in An Age of Globalization'. Contemporary Politics 17 (1): 53-69. 